\title{
Smartphone and Internet Access and Utilization by People With Schizophrenia in South Australia: Quantitative Survey Study
}

Kwok Tung Gordon Wong ${ }^{1}$, B Psych, BSocSc (Psych) (Hons); Dennis Liu ${ }^{2,3}, \mathrm{MBChB}, \mathrm{PhD}$; Ryan Balzan ${ }^{4,5}$, PhD; Daniel King ${ }^{5}$, PhD; Cherrie Galletly ${ }^{2,3,6}, \mathrm{MBChB}, \mathrm{PhD}$

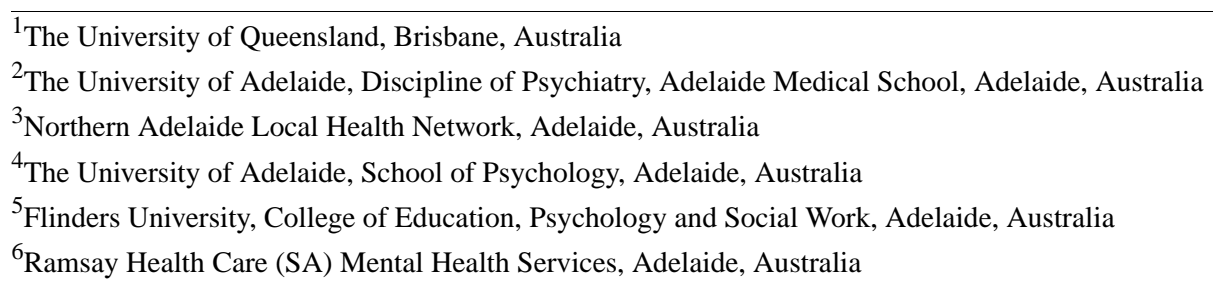

Corresponding Author:

Cherrie Galletly, MBChB, PhD

The University of Adelaide

Discipline of Psychiatry, Adelaide Medical School

Helen Mayo North, Frome Road

Adelaide, 5000

Australia

Phone: 6182698144

Email: cherrie.galletly@ adelaide.edu.au

\section{Abstract}

Background: Web-based information and interventions for mental illness are increasingly being provided. There is an expectation that citizens have access to the internet and are competent in using technology. People with schizophrenia are often excluded from social engagement, have cognitive impairment, and have very limited income, all of which may reduce their use of technology.

Objective: This study aimed to investigate technology access, use of digital technology, and confidence in using technology among people with schizophrenia living in the community.

Methods: Face-to-face structured interviews with 50 people with schizophrenia (aged 18-65 years) living in the northern suburbs of Adelaide, South Australia, were conducted using an instrument designed to assess technology access and utilization.

Results: Most participants (42/50, 84\%) owned a mobile phone, but only 58\% (29/50) owned a smartphone. Two-thirds of participants $(33 / 50,66 \%)$ had access to the internet at home, using a smartphone or computer. Moreover, 40\% (20/50) of participants used the internet at least daily, but 30\% (15/50) of participants had never accessed the internet from any device. Approximately half of the participants $(24 / 50,48 \%)$ had never used Facebook. Participants rarely used community facilities (eg, libraries and cafes) to access the internet. There were no significant differences ( $P$ values ranged from .14 to .70$)$ between younger participants (aged 18-34 years) and older participants (aged 35-64 years) in internet or smartphone access or confidence in using technology.

Conclusions: Although the sample size of this study is small, it shows limited technology access, use of digital technology, and confidence in using technology among the participants. This could be a barrier to the online delivery of information and interventions for people with schizophrenia. To better understand the impacts of such technological disadvantage and potential disparities in access and use of online resources, prospective studies should recruit a larger sample size and include control subjects matched for socioeconomic disadvantage.

(JMIR Ment Health 2020;7(1):e11551) doi: $\underline{10.2196 / 11551}$

\section{KEYWORDS}

schizophrenia; schizoaffective disorder; internet; technology; computer; smartphone 


\section{Introduction}

\section{Background}

Electronic mental (e-mental) health interventions are increasingly being implemented to assist in the management of psychiatric disorders and improve access to early intervention $[1,2]$. Those interventions apply information and communication technology, eg, computers and smartphones, to help promote mental well-being [1]. Although many of these interventions are aimed at high-prevalence mental health issues, eg, anxiety and depression [3], some specifically target people with psychotic disorders [4]. Emerging research suggests that engagement with cost-effective online interventions may be feasible for adults with a schizophrenia spectrum disorder [5]. For example, Alvarez-Jimenez et al [4] used an online platform to deliver clinical interventions to young people with early schizophrenia. Montes et al [6] found that the use of SMS text messages can improve antipsychotic medication adherence in people with schizophrenia, and studies by Ainsworth et al [7] and Ben-Zeev et al [8] demonstrated that smartphones could be beneficial in delivering interventions to patients with schizophrenia.

A systematic review by Alvarez-Jimenez et al [5] found that online, social media, and mobile phone-based interventions show promise in reducing the severity of positive symptoms and depression, reducing hospital admissions, improving social contacts, and enhancing medication adherence. There has been limited research on technology access (such as computers and smartphones), use of digital technology, and the level of confidence in using technology among individuals with schizophrenia. Access to technology is fundamental for the implementation of e-mental health.

In addition to potentially limiting access to e-mental health interventions, limited access to and use of technology could be associated with low levels of workforce engagement $[9,10]$, reduced access to essential services (eg, government departments and financial institutions) [10] and transport systems [11], and limited access to social media [12]. Those factors could further impair social exclusion.

Miller et al [12] surveyed 80 inpatients and outpatients with schizophrenia at a university psychiatry service in the United States. They found that $56 \%$ of patients used text messaging, $48 \%$ had an email account, and $27 \%$ used social networking sites regularly. Gay et al [13] reported that of 457 people with schizophrenia, 24\% used Web-based technology to help identify coping strategies, $42 \%$ listened to music to help block or manage voices, and $28 \%$ used technology to set alarms or reminders for medication management. However, Gay et al [13] used an online survey to collect this information; therefore, their sample was biased to those comfortable with online activities and did not include people who lacked internet access or competence using technology. A propensity weighting method was used to adjust for socioeconomic, attitudinal, and behavioral differences between people who respond to Web-based surveys and those who do not, but this appeared to be based on the general population rather than taking into account specific differences between those with schizophrenia and the rest of the community.
Torous et al [14] reported substantial differences according to socioeconomic status. Only $33 \%$ of outpatients attending a state mental health clinic in the United States owned a smartphone and were willing to use it to monitor psychiatric symptoms, compared with $72 \%$ of those attending a private clinic [14]. Glick et al [15] surveyed 100 people with severe mental illness attending a public sector community mental health center in Atlanta, United States. They found that $85 \%$ of their participants had a cell phone and $37 \%$ had a smartphone, compared with $53 \%$ in a general population survey, and $44 \%$ of the socioeconomically disadvantaged people in the general community had smartphones. Both Torous et al [14] and Glick et al [15] surveyed outpatient populations that included a range of psychiatric diagnoses. In the study by Glick et al [15], 29.2\% of people had schizophrenia or schizoaffective disorder, and Torous et al [14] did not include diagnostic information. Similarly, Ennis et al [9] drew participants from an early psychosis unit and from community mental health services in London. They did not give detailed diagnostic information. They found that technology use and access were similar to the general population. Collectively, those studies about the access to technology and the use of technology in patients with a schizophrenia spectrum disorder appeared inconclusive, which suggests a need for further investigation in those areas. Nonetheless, those findings correspond to the findings by Firth et al [16] who showed that smartphone app-based interventions for the whole population of patients with schizophrenia are not feasible when a significant portion of these people have no access to a smartphone. Together, those studies have justified the need to further investigate and understand their technology access and use, rather than implementing e-mental health interventions in the said population.

There are some specific aspects of schizophrenia that would be expected to be relevant in this study's context. People with schizophrenia generally have some cognitive impairment [17], which would impact the ability to learn new skills using unfamiliar devices. Negative symptoms (eg, avolition and poor initiative), lack of social networks [18], and paranoid ideation [12] may also reduce engagement with technology. Furthermore, most people with psychotic disorders have very limited income [19]; hence, the purchase of smartphones and computers may not be possible. Libraries generally have computers with internet access that can be used by the general public, and internet access is available in many cafes, yet the usage of these low-cost options by people with schizophrenia is not known.

This study took place in the northern suburbs of Adelaide, a region with a low socioeconomic status. The official rate of unemployment is $7.7 \%$, which is higher than that in other metropolitan areas in South Australia. Almost two-thirds (62\%) of the population had not completed secondary school education [19], and in 2016, more than three-quarters (77\%) of the northern population had received government benefits for more than 1 year [20]. The health status of people residing in this region is generally poorer than that of people residing in other regions in South Australia, with one-quarter of residents (25\%) reported to have a serious or chronic health condition [21]. 


\section{Objectives}

The first objective of this study was to investigate technology access, use of digital technology, and confidence in using technology in people with schizophrenia living in a socioeconomically deprived urban region in Adelaide, Australia. The second objective was to compare internet usage, frequency of internet use, and confidence in using technology in younger and older adults with schizophrenia.

\section{Methods}

\section{Recruitment}

For this quantitative survey study, a member of the research team, psychiatrist (DL), identified stable outpatients with schizophrenia attending the Northern Adelaide Local Health Network (NALHN) community mental health center who were interested in participating in research. Afterward, another research team member $(\mathrm{GW})$ recruited them for the study.

A total of 51 adults agreed to participate, but 1 of them was then found to have a diagnosis other than schizophrenia or schizoaffective disorder, resulting in the final sample of 50 adults. On participation, each participant was given an Aus \$20 shopping gift card to reimburse their time. Owing to the budget allocated for this research project, only 50 adults with schizophrenia were recruited.

\section{Participants and Exclusion Criteria}

To ensure that participants had the capacity to consent for participation, individuals with a history of moderate/severe head injury, neurological disorders, or mental retardation (ie, IQ<70 as determined by the National Adult Reading Test [NART] [22]) were excluded.

\section{Survey}

Two of the research team members (GW and CG, a psychiatrist) were responsible for the conceptualization and selection of this study's survey constructs, based on professional experiences in working with outpatients with schizophrenia. In addition to the NART, this study's interview consisted of Peters et al Delusions Inventory 21 [23], which measures delusion proneness. There were also items of demographic information and mental health history developed from a recent Australian study, People Living with Psychotic Illness 2010 [19]. Moreover, 80 individual technology-related questions that were used in this study were modified from surveys developed by Ennis et al [9], Muñoz-Neira et al [24], and Miller et al [12]. These questions assessed the following domains: (1) access, prevalence, and frequency of use of computers and mobile phones in general; (2) use of online resources (eg, banking, navigation, online shopping, email, social media, and well-being); and (3) attitudes to technology and self-rated competence.

For further details about this study's survey, please see Multimedia Appendix 1.

\section{Procedure}

The Human Research Ethics Committee of The Queen Elizabeth Hospital, Adelaide, South Australia, approved this research project. Before participation, GW explained to each participant the purpose of the study, what the participation entailed, the potential risks involved, and that they were free to withdraw without prejudice. Each participant was also given a copy of the study's participant information sheet and consent form. All participants gave written informed consent. The recruitment flowchart is shown in Figure 1. Individual interviews were conducted in the NALHN mental health sites, including a hospital-based clinical trials unit and a psychosocial rehabilitation and day program club, by a community rehabilitation worker (GW) under supervision. Instead of asking the study's participants to fill out the study questionnaire themselves, the primary researcher $(\mathrm{GW})$ interviewed the participants as a means to gauge their understanding of the questionnaire questions. The interviews lasted for 45 to $60 \mathrm{~min}$ each.

Figure 1. Recruitment flow-chart for this study.

\begin{tabular}{|l|l|l|l|}
$\begin{array}{l}\text { A clinical lead } \\
\text { psychiatrist (Dennis Liu) } \\
\text { of Northern Adelaide } \\
\text { Local Health Network } \\
\text { identified and } \\
\text { established a list of adult } \\
\text { patients with a } \\
\text { schizophrenia spectrum } \\
\text { disorder suitable for the } \\
\text { study, which filtered out } \\
\text { patients known to have } \\
\text { a history of moderate or } \\
\text { severe head injury, } \\
\text { neurological disorders, } \\
\text { or an IQ<70. }\end{array}$ \\
\hline
\end{tabular}




\section{Data Analysis}

Chi-square tests were used to investigate whether younger participants (aged 18-34 years) had better technology access and more confidence in using technology than older participants (aged 35-64 years).

\section{Results}

\section{Demographics}

Participants were predominantly male with schizophrenia and were supported by government pensions. Moreover, 30\% (15/50) of the participants were aged between 18 and 34 years, 30\% (15/50) were aged between 35 and 44 years, and another $30 \%$ (15/50) were aged between 45 and 54 years. The remaining participants $(5 / 50,10 \%)$ were aged between 55 and 65 years (Table 1). In addition, 40\% (20/50) of the participants had completed secondary school education; 52\% (26/50) of the participants used Facebook, and their mean number of friends on Facebook was 52.86 (SD 114.58). Most participants (43/50,
$86 \%)$ had been in contact with mental health services for 7 years or more, and 94\% (47/50) of the participants took atypical antipsychotic medication.

\section{Ownership of Devices and Usage}

Overall, 42 participants $(42 / 50,84 \%)$ owned a mobile phone, but only $29(29 / 50,58 \%)$ owned a smartphone. In addition, 26 participants $(26 / 50,52 \%)$ owned a personal computer, and 14 participants $(14 / 50,28 \%)$ owned a tablet. Half of the participants owned more than 1 device. Table 2 shows the rates of use of technology, with $76 \%$ (38/50) using their devices at least weekly.

Regarding smartphone use, only 44\% (22/50) of the participants had ever downloaded an app, and 38\% (19/50) of the participants used GPS or navigated using maps; in contrast, the majority of the participants had used their device's calendar $(35 / 50,70 \%)$, calculator $(33 / 50,66 \%)$, alarm $(30 / 50,60 \%)$, and camera $(31 / 50$, $62 \%$ ). Only $32 \%$ (16/50) of the participants used their computers for more complex tasks such as word processing. 
Table 1. Sociodemographic and clinical description of the sample $(\mathrm{N}=50)$.

\begin{tabular}{|c|c|}
\hline Characteristics & Value \\
\hline \multicolumn{2}{|l|}{ Gender, n (\%) } \\
\hline Male & $31(62)$ \\
\hline Female & $19(38)$ \\
\hline \multicolumn{2}{|l|}{ Age (years), n (\%) } \\
\hline $18-34$ & $15(30)$ \\
\hline $35-44$ & $15(30)$ \\
\hline $45-54$ & $15(30)$ \\
\hline $55-65$ & $5(10)$ \\
\hline \multicolumn{2}{|l|}{ Highest education completed, $\mathrm{n}(\%)$} \\
\hline Did not complete year 9 & $3(6)$ \\
\hline Did not complete secondary school (year 12), no postsecondary school qualifications & $25(50)$ \\
\hline Secondary school certificate & $7(14)$ \\
\hline Postschool qualification (trade certificate or higher) & $13(26)$ \\
\hline Unsure & $1(2)$ \\
\hline Did not answer & $1(2)$ \\
\hline \multicolumn{2}{|l|}{ Income (some had more than 1 source of income), $n(\%)$} \\
\hline Government pension & $50(100)$ \\
\hline Full-time work & $1(2)$ \\
\hline Part-time work & $5(10)$ \\
\hline Casual work & $2(4)$ \\
\hline Financial support from family & $14(28)$ \\
\hline Financial support from other people & $3(6)$ \\
\hline \multicolumn{2}{|l|}{ Diagnosis, $\mathbf{n}(\%)$} \\
\hline Schizophrenia & $43(86)$ \\
\hline Schizoaffective disorder & $7(14)$ \\
\hline \multicolumn{2}{|l|}{ Duration of involvement with mental health services, $n(\%)$} \\
\hline 1 to $<3$ years & $1(2)$ \\
\hline 3 to $<5$ years & $1(2)$ \\
\hline 5 to $<7$ years & $5(10)$ \\
\hline$\geq 7$ years & $43(86)$ \\
\hline Admitted to a mental health unit in the last 12 months & $24(48)$ \\
\hline \multicolumn{2}{|l|}{ Medication, n (\%) } \\
\hline Typical antipsychotic medication & $4(8)$ \\
\hline Atypical antipsychotic medication & $47(94)$ \\
\hline Antidepressant medication & $22(44)$ \\
\hline Antianxiety medication & $2(4)$ \\
\hline Anticholinergic medication & $2(4)$ \\
\hline \multicolumn{2}{|l|}{ Peters et al Delusions Inventory 21, mean (SD) } \\
\hline Total score & $70.26(13.67)$ \\
\hline Yes/no score & $7.32(4.55)$ \\
\hline Distress score & $20.18(15.89)$ \\
\hline Preoccupation score & $20.40(15.81)$ \\
\hline
\end{tabular}




\begin{tabular}{lc}
\hline Characteristics & Value \\
\hline Conviction score & $22.32(16.24)$ \\
Intelligence score, mean (SD) & 103.06 (13.67) \\
$\quad$ Premorbid IQ (Wechsler Adult Intelligence Scale-Revised) score & 1 \\
\hline
\end{tabular}

Table 2. Access to technology $(\mathrm{N}=50)$.

\begin{tabular}{|c|c|c|c|c|c|c|c|c|c|c|c|c|}
\hline $\begin{array}{l}\text { Level of } \\
\text { frequency }\end{array}$ & $\begin{array}{l}\text { The use } \\
\text { of any } \\
\text { technolo- } \\
\text { gy de- } \\
\text { vices, } \mathrm{n} \\
(\%)\end{array}$ & $\begin{array}{l}\text { The use } \\
\text { of inter- } \\
\text { net, } \mathrm{n} \\
(\%)\end{array}$ & $\begin{array}{l}\text { Computer } \\
\text { access at } \\
\text { library or } \\
\text { communi- } \\
\text { ty center, } \\
\mathrm{n}(\%)\end{array}$ & $\begin{array}{l}\text { Wi-Fi ac- } \\
\text { cess at li- } \\
\text { brary or } \\
\text { cafe with } \\
\text { smart- } \\
\text { phone, n } \\
(\%)\end{array}$ & $\begin{array}{l}\text { Wi-Fi } \\
\text { access } \\
\text { at li- } \\
\text { brary } \\
\text { or cafe } \\
\text { with } \\
\text { laptop, } \\
\text { n (\%) }\end{array}$ & $\begin{array}{l}\text { The use } \\
\text { of Face- } \\
\text { book, } \mathrm{n} \\
(\%)\end{array}$ & $\begin{array}{l}\text { The } \\
\text { use of } \\
\text { email, } \\
\text { n (\%) }\end{array}$ & $\begin{array}{l}\text { The use } \\
\text { of inter- } \\
\text { net } \\
\text { bank- } \\
\text { ing, n } \\
(\%)\end{array}$ & $\begin{array}{l}\text { Making } \\
\text { online } \\
\text { pay- } \\
\text { ments, n } \\
(\%)\end{array}$ & $\begin{array}{l}\text { Engaging } \\
\text { in self-de- } \\
\text { velopment } \\
\text { study activ- } \\
\text { ities online, } \\
\mathrm{n}(\%)\end{array}$ & $\begin{array}{l}\text { Looking } \\
\text { and ap- } \\
\text { plying } \\
\text { for jobs } \\
\text { or stud- } \\
\text { ies on- } \\
\text { line, } \mathrm{n} \\
(\%)\end{array}$ & $\begin{array}{l}\text { Frequency } \\
\text { of using } \\
\text { the internet } \\
\text { to look up } \\
\text { health-relat- } \\
\text { ed informa- } \\
\text { tion, n (\%) }\end{array}$ \\
\hline Never & $9(18)$ & $15(30)$ & $34(68)$ & $43(86)$ & $\begin{array}{l}48 \\
(96)\end{array}$ & $24(48)$ & $\begin{array}{l}19 \\
(38)\end{array}$ & $28(56)$ & $33(66)$ & $35(70)$ & $33(66)$ & $27(54)$ \\
\hline $\begin{array}{l}\text { Less than } \\
\text { monthly }\end{array}$ & $1(2)$ & $3(6)$ & $8(16)$ & $4(8)$ & $2(4)$ & $4(8)$ & $4(8)$ & $3(6)$ & $6(12)$ & $6(12)$ & $6(12)$ & $6(12)$ \\
\hline Monthly & $0(0)$ & $3(6)$ & $5(10)$ & $2(4)$ & $0(0)$ & $4(8)$ & $6(12)$ & $3(6)$ & $4(8)$ & $4(8)$ & $3(6)$ & $11(22)$ \\
\hline $\begin{array}{l}\text { Fortnight- } \\
\text { ly }\end{array}$ & $1(2)$ & $0(0)$ & $0(0)$ & $0(0)$ & $0(0)$ & $0(0)$ & $0(0)$ & $2(4)$ & $0(0)$ & $0(0)$ & $0(0)$ & $0(0)$ \\
\hline Weekly & $1(2)$ & $3(6)$ & $1(2)$ & $0(0)$ & $0(0)$ & $0(0)$ & $3(6)$ & $0(0)$ & $3(6)$ & $0(0)$ & $0(0)$ & $0(0)$ \\
\hline $\begin{array}{l}\text { More } \\
\text { than } \\
\text { weekly }\end{array}$ & $5(10)$ & $6(12)$ & $2(4)$ & $1(2)$ & $0(0)$ & $2(4)$ & $4(8)$ & $9(18)$ & $3(6)$ & $3(6)$ & $6(12)$ & $2(4)$ \\
\hline Daily & $20(40)$ & $12(24)$ & $0(0)$ & $0(0)$ & $0(0)$ & $12(24)$ & $\begin{array}{l}10 \\
(20)\end{array}$ & $5(10)$ & $1(2)$ & $2(4)$ & $1(2)$ & $4(8)$ \\
\hline $\begin{array}{l}\text { More } \\
\text { than daily }\end{array}$ & $13(26)$ & $8(16)$ & $0(0)$ & $0(0)$ & $0(0)$ & $4(8)$ & $4(8)$ & $0(0)$ & $0(0)$ & $0(0)$ & $1(2)$ & $0(0)$ \\
\hline
\end{tabular}

\section{Internet Access}

Two-thirds $(33 / 50,66 \%)$ of the participants had access to the internet at home, using a smartphone, computer, or both. In addition, $40 \%(20 / 50)$ of the participants used the internet at least daily (Table 2). However, 30\% (15/50) of the participants had never accessed the internet from any device. Community facilities, such as cafes, libraries, and community centers, which provide internet access, were rarely used for this purpose by the participants in this study.

Of the participants using the internet, $44 \%$ (22/50) used it for internet banking and $30 \%(15 / 50)$ to $34 \%$ (17/50) used it for online shopping, for making online payments, for applying for jobs or courses online, or for engaging with self-development activities. Only half of the participants with internet access used the internet for searching for local businesses $(24 / 50,48 \%)$ or to plan trips $(25 / 50,50 \%)$. Moreover, 54\% (27/50) of the participants never used the internet to look up health-related information online, and 38\% (19/50) of the participants reported that they could not find an Australian website about depression.

\section{Digital Communication}

Most participants $(44 / 50,88 \%)$ used mobile phones at least weekly to make and receive calls, with a lower proportion (32/50, 64\%) using text messaging, and 38\% (19/50) never used email. Social media was not routinely used, and $48 \%(24 / 50)$ and $90 \%(45 / 50)$ of the participants had never used Facebook and Twitter, respectively, on any device.

\section{Attitudes to Technology}

About 1 in 3 participants were not confident with using smartphone devices (Table 3). Fewer than half of the participants reported that they would have trouble with their day-to-day life if they did not have access to the internet $(22 / 50,44 \%)$, computer $(22 / 50,44 \%)$, or their smartphone devices $(21 / 50$, $42 \%)$.

A higher percentage of people aged 18 to 34 years used the internet at home $(11 / 15,73 \%)$, used the internet daily $(7 / 15$, $47 \%$ ), and had greater confidence in using a computer or smartphone $(60 \%)$ compared with people aged 35 to 64 years $(22 / 35,63 \% ; 13 / 35,37 \%$; and $29 \%$ respectively). However, these differences between the 2 age groups were not statistically significant (Table 3 ). 
Table 3. Internet usage, internet frequency, and confidence in using technology by age $(\mathrm{N}=50)$.

\begin{tabular}{|c|c|c|c|c|}
\hline $\begin{array}{l}\text { Internet usage, internet frequency, and confidence in using } \\
\text { technology by age }\end{array}$ & $18-34$ years $(\mathrm{n}=15), \mathrm{n}(\%)$ & $35-64$ years $(\mathrm{n}=35), \mathrm{n}(\%)$ & Chi-square $(d f)$ & $P$ value \\
\hline Use internet on computer or mobile phone at home & & & $0.2(1)$ & .70 \\
\hline No & $4(27)$ & $13(37)$ & & \\
\hline Yes & $11(73)$ & $22(63)$ & & \\
\hline Frequency of internet use & & & $2.4(3)$ & .50 \\
\hline Never & $3(20)$ & $12(34)$ & & \\
\hline Monthly or less & $1(7)$ & $5(14)$ & & \\
\hline Weekly & $4(27)$ & $5(14)$ & & \\
\hline Fortnightly & $0(0)$ & $0(0)$ & & \\
\hline Daily & $7(47)$ & $13(37)$ & & \\
\hline Confidence in using computer & & & $1.2(2)$ & .56 \\
\hline Not at all confident & $6(40)$ & $13(37)$ & & \\
\hline Somewhat confident & $3(20)$ & $12(34)$ & & \\
\hline Confident or very confident & $6(40)$ & $10(29)$ & & \\
\hline Confidence in using smartphone & & & $3.9(3)$ & .14 \\
\hline Not at all confident & $5(33)$ & $11(31)$ & & \\
\hline Somewhat confident & $1(7)$ & $11(31)$ & & \\
\hline Confident or very confident & $9(60)$ & $13(37)$ & & \\
\hline
\end{tabular}

\section{Discussion}

\section{Principal Findings}

Overall, technology access and engagement were lower in this study than in the rest of the Australian community. The prevalence of owning a computer $(26 / 50,52 \%)$ or smartphone $(29 / 50,58 \%)$ in our participants was lower than that in the Australian population (62\% and $76 \%$, respectively) [25]. Similarly, in 2016, it was estimated that $87 \%$ of Australians used the internet daily [26], compared with 40\% (20/50) of our participants with schizophrenia, and 50\% of Australians used social networking sites daily, compared with $32 \%(16 / 50)$ in our sample. Approximately 30\% (15/50) of our sample had never accessed the internet.

Our results showed that most participants were only using certain device functions (eg, calling and SMS text messaging) and rarely used other functions of digital technology (eg, internet banking, social networking, self-development, health maintenance, and navigation). There was little use of e-mental health therapeutic interventions or psychoeducational sites.

Some studies provide smartphones to enable participants in research projects using e-mental health interventions. In contrast, participants in other research projects are required to use their own smartphone. Treisman et al [25] attributed the lack of engagement with technology by some people with schizophrenia to the cost of devices and lack of skills. Glick et al [15] argue that smartphones and internet plans are becoming affordable, but people with psychoses often describe living in poverty. In an Australian survey in 2010, $12 \%$ of the study sample reported having run out of food in the previous 12 months, and not having money to buy more [12]. In addition, it is possible that the costs associated with a technology device [27], a lack of knowledge about what device to buy, and how to set up internet access may be barriers to use. Furthermore, cognitive impairment is a core symptom of schizophrenia [28,29], so learning to use unfamiliar devices and to acquire technology skills could be challenging.

Increasingly, social engagement occurs via social media, and information from a wide variety of sources is provided online rather than using more traditional methods of communication. Many people with psychosis, including schizophrenia, experience social isolation [30,31], potentially with a lack of meaningful social participation. It appears that one-third of the participants would be unable to engage in social media. However, less than half of the participants showed that they would never struggle with their daily life if they had no access to the internet, computer, or their smartphone. Although the rationale was not investigated, such phenomena could be related to an adaptation to live without those technologies or the individual's regular psychosocial rehabilitation support, which may include side-by-side assistance for activities of daily living offered by mental health support workers and clinicians, reducing the need to use technologies independently.

This study provides data on the level of access to digital technology and the self-reported confidence among adults with schizophrenia living in a socioeconomically deprived urban region in Australia. These findings may have implications for the design and scope of delivery of e-mental health interventions for this particular population, especially when there are e-mental health interventions that target psychoeducation (via the internet) and medication adherence (via SMS text messages) [32]. Yet, using e-mental health interventions requires a certain level of technology access, use, and confidence. When patients with 
schizophrenia do not use digital technology or lack the confidence to use it, they may not be able to fully use those e-mental health interventions.

\section{Future Directions}

Prospective studies may need to address barriers that prevent greater engagement with technology in this population, including paranoia [12], mistrust of devices, and access to the internet. Further research could also examine the barriers to accessing the internet in public areas (eg, public libraries), given that these resources were rarely used. Needless to mention that, in the NALHN's service catchment area, at least three libraries with free internet access and training are located within walking distances to the corresponding major shopping centers and supermarkets. This is particularly concerning, as the cost of purchasing devices and maintaining internet access may simply be too expensive for many people with schizophrenia, and these free services may be a useful means of access. Specific familiarization programs are needed to help with awareness of these facilities and with feeling welcome when attending. Ultimately, improved access and encouraging patients with schizophrenia to learn how to use technology may promote a greater range of technology uses, potentially including therapeutic interventions.

\section{Limitations}

The small sample size of this study limits generalizability. In addition, instead of assessing real-time usage and skills as a technology literacy assessment, this study relied on self-reported frequency of technology usage. This study did not assess technology literacy. In other words, this study did not capture the extent to which participants could carry out a task, eg, asking them to navigate a website, perform a search, and note any difficulties they encounter. Nonetheless, this research has tapped into the participants' confidence level regarding technology use. Future research could also include an economically and demographically matched healthy control group to more thoroughly examine factors unique to individuals with schizophrenia.

\section{Conclusions}

In conclusion, digital technology use and internet access were limited in this population. This may be addressed via the delivery of training to increase individuals' confidence in the use of technology. This training may be required before the online delivery of e-mental health interventions can be widely used in people with schizophrenia. Further research should examine the extent to which paranoia, cognitive deficits, and poverty limit people with schizophrenia from engaging with e-mental health interventions, smartphones, and computers to improve their mental health.

\section{Authors' Contributions}

All authors contributed to the manuscript and revised and approved the final draft.

\section{Conflicts of Interest}

None declared.

\section{Multimedia Appendix 1}

Demographic information.

[DOCX File , 28 KB-Multimedia Appendix 1]

\section{References}

1. Riper H, Andersson G, Christensen H, Cuijpers P, Lange A, Eysenbach G. Theme issue on e-mental health: a growing field in internet research. J Med Internet Res 2010 Dec 19;12(5):e74 [FREE Full text] [doi: 10.2196/jmir.1713] [Medline: 21169177]

2. Krieke JA. Patients in the Driver's Seat: A Role for E-mental Health?. 2014. URL: https://www.rug.nl/research/portal/files/ 14432329/Complete\%20dissertation [accessed 2019-11-20]

3. Donker T, Petrie K, Proudfoot J, Clarke J, Birch MR, Christensen H. Smartphones for smarter delivery of mental health programs: a systematic review. J Med Internet Res 2013 Nov 15;15(11):e247 [FREE Full text] [doi: 10.2196/jmir.2791] [Medline: 24240579]

4. Alvarez-Jimenez M, Bendall S, Lederman R, Wadley G, Chinnery G, Vargas S, et al. On the HORYZON: moderated online social therapy for long-term recovery in first episode psychosis. Schizophr Res 2013 Jan;143(1):143-149. [doi: 10.1016/j.schres.2012.10.009] [Medline: 23146146]

5. Alvarez-Jimenez M, Alcazar-Corcoles MA, González-Blanch C, Bendall S, McGorry PD, Gleeson JF. Online, social media and mobile technologies for psychosis treatment: a systematic review on novel user-led interventions. Schizophr Res 2014 Jun;156(1):96-106. [doi: 10.1016/j.schres.2014.03.021] [Medline: 24746468]

6. Montes JM, Medina E, Gomez-Beneyto M, Maurino J. A short message service (SMS)-based strategy for enhancing adherence to antipsychotic medication in schizophrenia. Psychiatry Res 2012 Dec 30;200(2-3):89-95. [doi: 10.1016/j.psychres.2012.07.034] [Medline: 22901437]

7. Ainsworth J, Palmier-Claus JE, Machin M, Barrowclough C, Dunn G, Rogers A, et al. A comparison of two delivery modalities of a mobile phone-based assessment for serious mental illness: native smartphone application vs text-messaging 
only implementations. J Med Internet Res 2013 Apr 5;15(4):e60 [FREE Full text] [doi: 10.2196/jmir.2328] [Medline: 23563184]

8. Ben-Zeev D, Brenner CJ, Begale M, Duffecy J, Mohr DC, Mueser KT. Feasibility, acceptability, and preliminary efficacy of a smartphone intervention for schizophrenia. Schizophr Bull 2014 Nov;40(6):1244-1253 [FREE Full text] [doi: 10.1093/schbul/sbu033] [Medline: 24609454]

9. Ennis L, Rose D, Denis M, Pandit N, Wykes T. Can't surf, won't surf: the digital divide in mental health. J Ment Health 2012 Aug;21(4):395-403 [FREE Full text] [doi: 10.3109/09638237.2012.689437] [Medline: 22712756]

10. McLaren J, Zappalà G. BSL catalogue. 2002. The New Economy Revisited: An Initial Analysis of the Digital Divide Among Financially Disadvantaged Families. URL: http://library.bsl.org.au/jspui/bitstream/1/431/1/ The\%20new\%20economy\%20revisited.pdf [accessed 2019-11-20]

11. Mackett R. Assets: how they work. 2017 Nov. Building Confidence - Improving Travel for People With Mental Impairments. URL: https://assets.publishing.service.gov.uk/government/uploads/system/uploads/attachment data/file/662737/ report-on-mental-impairments_final.pdf [accessed 2019-11-20]

12. Miller BJ, Stewart A, Schrimsher J, Peeples D, Buckley PF. How connected are people with schizophrenia? Cell phone, computer, email, and social media use. Psychiatry Res 2015 Feb 28;225(3):458-463. [doi: 10.1016/j.psychres.2014.11.067] [Medline: 25563669]

13. Gay K, Torous J, Joseph A, Pandya A, Duckworth K. Digital technology use among individuals with schizophrenia: results of an online survey. JMIR Ment Health 2016 May 4;3(2):e15 [FREE Full text] [doi: 10.2196/mental.5379] [Medline: 27146094]

14. Torous J, Chan SR, Tan SY, Behrens J, Mathew I, Conrad EJ, et al. Patient smartphone ownership and interest in mobile apps to monitor symptoms of mental health conditions: a survey in four geographically distinct psychiatric clinics. JMIR Ment Health 2014;1(1):e5 [FREE Full text] [doi: 10.2196/mental.4004] [Medline: 26543905]

15. Glick G, Druss B, Pina J, Lally C, Conde M. Use of mobile technology in a community mental health setting. J Telemed Telecare 2016 Oct;22(7):430-435. [doi: 10.1177/1357633X15613236] [Medline: 26519378]

16. Firth J, Cotter J, Torous J, Bucci S, Firth JA, Yung AR. Mobile phone ownership and endorsement of 'mHealth' among people with psychosis: a meta-analysis of cross-sectional studies. Schizophr Bull 2016 Mar;42(2):448-455 [FREE Full text] [doi: 10.1093/schbul/sbv132] [Medline: 26400871]

17. American Psychiatric Association. Diagnostic and Statistical Manual of Mental Disorders. Fifth Edition. Washington, DC: American Psychiatric Publishing, Inc; 2013.

18. Green MF, Horan WP, Lee J, McCleery A, Reddy LF, Wynn JK. Social disconnection in schizophrenia and the general community. Schizophr Bull 2018 Feb 15;44(2):242-249 [FREE Full text] [doi: 10.1093/schbul/sbx082] [Medline: 28637195]

19. Morgan VA, Waterreus A, Jablensky A, Mackinnon A, McGrath JJ, Carr V. People Living With Psychotic Illness 2010: Report on the Second National Survey. Canberra, Australia: Commonwealth of Australia; 2011.

20. Australian Bureau of Statistics. 2018. Labour force status by Labour market region (ASGS) and Sex. URL: https://www. abs.gov.au/AUSSTATS/abs@.nsf/DetailsPage/6291.0.55.001Dec\%202016?OpenDocument [accessed 2019-11-20]

21. Public Health Information Development Unit. Atlases Australia. South Australia, Australia: Public Health Information Development Unit; 2017. An Atlas of Respiratory Conditions in South Australia: Population Patterns of Prevalence, Risk Factors, Service Use and Treatment. URL: http://www.atlasesaustralia.com.au/respiratory/Respiratory\%20atlas.pdf [accessed 2019-11-25]

22. Nelson HE, Willison J. Academia. Windsor, UK: NFER-Nelson; 1991. The National Adult Reading Test (NART). URL: https://www.academia.edu/2515150/National Adult Reading Test NART test manual Part 1 [accessed 2019-11-25]

23. Peters E, Joseph S, Day S, Garety P. Measuring delusional ideation: the 21-item Peters et al. Delusions Inventory (PDI). Schizophr Bull 2004;30(4):1005-1022. [doi: 10.1093/oxfordjournals.schbul.a007116] [Medline: 15954204]

24. Muñoz-Neira C, López OL, Riveros R, Núñez-Huasaf J, Flores P, Slachevsky A. The technology - activities of daily living questionnaire: a version with a technology-related subscale. Dement Geriatr Cogn Disord 2012;33(6):361-371 [FREE Full text] [doi: 10.1159/000338606] [Medline: 22797087]

25. Treisman GJ, Jayaram G, Margolis RL, Pearlson GD, Schmidt CW, Mihelish GL, et al. Perspectives on the use of eHealth in the management of patients with schizophrenia. J Nerv Ment Dis 2016 Aug;204(8):620-629 [FREE Full text] [doi: 10.1097/NMD.0000000000000471] [Medline: 26828911]

26. Sensis. multi-screen site. 2016 Jun 1. Sensis Social Media Report June 2016: How Australian People and Businesses Are Using Social Media. URL: https://irp-cdn.multiscreensite.com/535ef142/files/uploaded/Sensis Social Media Report 2016. pdf [accessed 2019-11-20]

27. Humphry J. The importance of circumstance: digital access and affordability for people experiencing homelessness. Aust J Telecommun Digit Econ 2014 Oct 20;2(3):55.1-55.15. [doi: 10.7790/ajtde.v2n3.55]

28. Daker-White G, Rogers A. What is the potential for social networks and support to enhance future telehealth interventions for people with a diagnosis of schizophrenia: a critical interpretive synthesis. BMC Psychiatry 2013 Nov 1;13:279 [FREE Full text] [doi: 10.1186/1471-244X-13-279] [Medline: 24180273]

29. Sanghara H, Kravariti E, Jakobsen H, Okocha C. Using short message services in mental health services: assessing feasibility. Ment Health Rev J 2010;15(2):28-33. [doi: 10.5042/mhrj.2010.0369] 
30. Badcock JC, Shah S, Mackinnon A, Stain HJ, Galletly C, Jablensky A, et al. Loneliness in psychotic disorders and its association with cognitive function and symptom profile. Schizophr Res 2015 Dec;169(1-3):268-273. [doi: 10.1016/j.schres.2015.10.027] [Medline: 26527247]

31. Lim MH, Gleeson JFM, Alvarez-Jimenez M, Penn DL. Loneliness in psychosis: a systematic review. Soc Psychiatry Psychiatr Epidemiol 2018 Mar;53(3):221-238. [doi: 10.1007/s00127-018-1482-5] [Medline: 29327166]

32. van der Krieke L, Wunderink L, Emerencia AC, de Jonge P, Sytema S. E-mental health self-management for psychotic disorders: state of the art and future perspectives. Psychiatr Serv 2014 Jan 1;65(1):33-49. [doi: 10.1176/appi.ps.201300050] [Medline: 24129842]

\title{
Abbreviations \\ e-mental: electronic mental \\ NALHN: Northern Adelaide Local Health Network \\ NART: National Adult Reading Test
}

\author{
Edited by G Eysenbach; submitted 18.07.18; peer-reviewed by B Greer, M Cernvall, T Campellone; comments to author 07.10.18; \\ revised version received 29.11.18; accepted 15.12.18; published 28.01.20 \\ Please cite as: \\ Wong KTG, Liu D, Balzan R, King D, Galletly C \\ Smartphone and Internet Access and Utilization by People With Schizophrenia in South Australia: Quantitative Survey Study \\ JMIR Ment Health 2020;7(1):e11551 \\ URL: https://mental.jmir.org/2020/1/e11551 \\ doi: $\underline{10.2196 / 11551}$ \\ PMID: 32012068
}

CKwok Tung Gordon Ann Wong, Dennis Liu, Ryan Balzan, Daniel King, Cherrie Galletly. Originally published in JMIR Mental Health (http://mental.jmir.org), 28.01.2020. This is an open-access article distributed under the terms of the Creative Commons Attribution License (https://creativecommons.org/licenses/by/4.0/), which permits unrestricted use, distribution, and reproduction in any medium, provided the original work, first published in JMIR Mental Health, is properly cited. The complete bibliographic information, a link to the original publication on http://mental.jmir.org/, as well as this copyright and license information must be included. 